\title{
Estética e poética da velhice em narrativas autobiográficas: um estudo à luz da psicanálise
}

\section{Aesthetics and poetics of aging on autobiographical narratives: A psychoanalytic study}

\section{La estética y la poética del envejecimiento en los relatos autobiográficos: un estudio a la luz del psicoanálisis}

\author{
Priscilla Melo Ribeiro de Lima* \\ Universidade Federal de Goiás, Goiânia, Goiás, Brasil
}

\section{Terezinha de Camargo Viana**}

Universidade de Brasília, Brasília, DF, Brasil

\author{
Sostenes Cezar de Lima*** \\ Universidade Estadual de Goiás, Anápolis, Goiás, Brasil
}

\begin{abstract}
RESUMO
O presente trabalho objetiva investigar, sob a lente da psicanálise, a (re)construção do eu na velhice. A escrita autobiográfica aponta a uma poética e a uma estética do eu enquanto (re)construção de si, e possibilita que o sujeito busque em sua história ferramentas para reinscrever-se no presente. Destaca-se ainda a relação do idoso com o tempo. A percepção da finitude da vida ressalta a sensação de desamparo e angústia. A rememoração pode surgir como forma de lidar com essa angústia. Concluise que a poiesis do sujeito possibilitada pela escrita de si pode auxiliá-lo a lidar com o presente e projetar-se no futuro. Isso pode (re)abrir caminhos para uma reconstrução do lugar social e simbólico do velho.
\end{abstract}

Palavras-chave: velhice, psicanálise, poiesis, estética, memória autobiográfica.

\section{ABSTRACT}

This study aims to investigate, under the lens of psychoanalysis, the (re) construction of the self in old age. The autobiographical writing points to a poetic and esthetic of the self while building itself, and allows the subject seeks in its history tools to re-enroll in the present. Another highlight is the relation of the elderly with time. The perception of the finitude of life emphasizes the feeling of helplessness and distress. The remembrance may arise as a way to deal with such distress. We conclude that the subject poiesis enabled by the writing of itself might help him to deal with the present and projecting himself into the future. This can (re) open ways for a reconstruction of the social and symbolic place of the elder.

Keywords: old age, psychoanalysis, poiesis, aesthetics, autobiographical memory. 


\begin{abstract}
RESUMEN
Este estudio tiene como objetivo investigar, con la lente del psicoanálisis, la (re) construcción del yo en la tercera edad. Los autobiográficos escritos indican a una poética y una estética del yo como (re) construcción del yo, y permite que el sujeto busca en sus herramientas de su historia para volver a inscribirse en este. Otro punto a destacar es la relación de las personas mayores con el tiempo. La percepción de la finitud de la vida destaca la sensación de impotencia y angustia. Los recuerdos pueden surgir como una forma de lidiar con esta ansiedad. Llegamos a la conclusión de que la poiesis del sujeto posiblitada por la propia escritura puede ayudarle a lidiar con el presente y proyectar hacia el futuro. Esto puede (re) abrir vías para una reconstrucción del lugar social y simbólico de la vejez.
\end{abstract}

Palabras clave: vejez, psicoanálisis, poiesis, estética, memoria autobiográfica.

\title{
1 Introdução
}

A estética, segundo Baumgarten (1735/1954), emergiu como um discurso voltado para o desvelamento da estrutura interna sensível de fenômenos racionais. Mais tarde, a partir de Descartes, incorporou também a admiração como um de seus elementos básicos. É pela admiração que o sujeito é levado a se aproximar dos objetos que lhe parecem raros e extraordinários e considerá-los cuidadosamente. Entretanto, o conhecimento obtido pela aproximação contemplativa não é, senão, um conhecimento marcado pela confusão, isto é, "os elementos da representação estética (...) resistem àquela discriminação em unidades discretas característica do pensamento conceitual" (Eagleton, 1990/2010) ${ }^{\times 1}$. Pode-se dizer que essa confusão se constrói a partir da junção de vários aspectos que se interpenetram e fogem à categorização racional, apesar de aberta a ela.

Poderíamos afirmar, concordando com Eagleton (1990/2010), que a estética atravessa a totalidade de nossa vida sensível e envolve "o movimento de nossos afetos e aversões, de como o mundo atinge 0 corpo em suas superfícies sensoriais, tudo aquilo enfim que se enraíza no olhar e nas vísceras". A estética, enquanto discurso sobre o corpo em Baumgarten, envolve a dimensão mais palpável da dimensão do humano implicando, dessa forma, uma existência sensual. Esse aspecto sensual emerge da interioridade do objeto externo e encontra consenso espontâneo no corpo do admirador.

A velhice constitui um objeto aberto à admiração, mesmo ante a perturbação imposta pelas perdas. Tanto o próprio velho quanto o sujeito não velho, uma vez abertos a novas percepções, podem construir novas experimentações para a velhice, tomando-a como objeto de contemplação. Rubem Alves, escritor mineiro, afirma que a experiência de se ver refletido nos olhos de uma moça no metrô o 
levou a se contemplar como velho. A partir daí, sua forma de olhar para si mesmo e para a velhice mudou. Algumas de suas crônicas mostram o modo como ele construiu uma estética para a velhice que transcendia a imagem do corpo envelhecido. Inconformado em ver a velhice como uma fase de aposentadoria da vida e de espera pela morte, Alves passa a extrair beleza, muitas vezes melancólica, de sua própria velhice. Em "O crepúsculo" (2001, pp. 21-34), descreve essa fase a partir dos componentes do entardecer:

"Há uma velhice em que as coisas amadas vão ficando cada vez mais distantes, perdidas no mar do esquecimento. E há uma outra velhice em que as coisas amadas perdidas voltam, ressuscitadas pela magia da saudade (...) Passada a surpresa estética da descoberta da velhice como crepúsculo, dei-me conta de que aquilo que via pela primeira vez era o que sempre tinha visto. O crepúsculo morara sempre dentro de mim. Aquilo que eu via era, na realidade, o que eu sempre fora. Isso explicava a incompreensível nostalgia que sempre me acompanhara. O gosto pela solidão. O medo do morrer. Pensei então que a velhice era coisa parecida: quando os olhos são atingidos pela luz do sol poente, o corpo reverbera, e dele sai uma melodia eternamente jovem. E me achei, então, muito bonito".

Parece inevitável pensar a estética sem a poética. Aristóteles em "Poética" (2007) e no livro VI de "Ética a Nicômaco" (1991) faz uma análise acerca da composição da poesia e de sua diferenciação da História. Ele afirma, na "Poética", que a função do poeta, ao imitar as ações e a vida, "não é contar o que aconteceu, mas aquilo que poderia acontecer, o que é possível" (2007, p. 54). Ao imitar, o poeta recria a realidade e acaba por enunciar verdades universais. Nesse sentido, a poiesis aponta para um posteriori, apesar de se basear no passado. Tanto a poética, conforme Aristóteles, quanto a estética, conforme Baumgarten, se presentificam na capacidade do poeta em transformar passado e presente em possibilidades de recriação do futuro.

Pode-se dizer que a poiesis se constrói a partir de duas funções: a fruição do belo e a (re)criação do mundo. Do ponto de vista da fruição, a poiesis é a via de acesso a questões particulares e universais que tocam o ser humano. Essa função é praticamente equivalente ao que estamos chamando aqui de estética que, segundo Aristóteles (2007), faz parte da essência da poesia. Escrever sobre o humano, sobre suas dores e alegrias, sobre suas relações com 0 tempo, com a natureza e com os outros, oferece tanto ao escritor quanto ao leitor-espectador uma catarse de suas emoções, afirma Freud (1905/1996f). O poeta retira de si mesmo os materiais para a 
construção do texto. O exercício de rememoração se torna, para o escritor criativo, um exercício contemplativo inevitável.

Do ponto de vista da segunda função, a (re)criação, pode-se dizer que $O$ ato de escrever (re)cria novas realidades e aperfeiçoa as velhas. A escrita de si, enquanto poiesis do eu, em escritos autobiográficos, não apenas reconta trajetórias, mas reconstrói o si mesmo. Borges (2000) nos lembra que "os antigos, quando falavam de um poeta - um 'fazedor' -, pensavam nele não somente como quem profere essas agudas notas líricas, mas também como quem narra uma história" (p. 51). Quando a história narrada é a própria história, aspectos do eu são transformados em palavras e podem ser remontados de diversas formas. A poiesis garante, assim, a (re)construção do próprio eu do poeta. Borges (2000) confessa que a existência das palavras o ajudou a tecer sua subjetividade e obter prazer: "Tirei prazer de muitas coisas, de nadar, escrever, contemplar um nascer do sol ou um crepúsculo, de estar apaixonado e assim por diante. Mas, de algum modo, o fato central de minha vida foi a existência das palavras e a possibilidade de tecê-las em poesia" ( $p$. 106).

Aristóteles (1991) ressalta que a arte intenciona a produção e a criação de algo; se ocupa em inventar e em considerar as maneiras de produzir algo "cuja origem está no que produz, e não no que é produzido" (p. 127). De forma semelhante aos sonhos e aos chistes, o inconsciente se apropria do acaso e de coisas aparentemente banais para, na escrita poietica, encontrar caminhos para a realização dos desejos. Há, portanto, um trabalho psíquico na escrita semelhante ao trabalho onírico. Freud (1908/1996c), compara o escritor criativo à criança. Assim como a criança se constrói e realiza seus desejos a partir do mundo fantástico, o escritor criativo utiliza suas fantasias para escrever e estetizá-las. Freud afirma: "As forças motivadoras das fantasias são desejos insatisfeitos, e toda fantasia é realização de um desejo, uma correção da realidade insatisfatória" (p. 137). As fantasias estão intimamente ligadas ao tempo e "adaptamse às impressões mutáveis que o sujeito tem da vida, alterando-se a cada mudança de situação e recebendo de cada nova impressão ativa uma espécie de 'carimbo de data de fabricação'"' (p. 138).

A cada nova abordagem de um mesmo fato, novas significações são feitas. Bakhtin afirma que o objetivo do artista é encontrar o enfoque essencial à vida de fora dela. "O artista e a arte criam, em linhas gerais, uma visão absolutamente nova do mundo" (1979/2010, p. 176). Cada nova escrita gera nova visão de mundo e de vida. O trabalho do escritor é, portanto, uma reescrita do passado e de sua própria subjetividade.

A arte, especialmente na poietica, se apresenta como solução diante questões em que o discernimento e linguagem falham. A busca pelo belo e sua transubstanciação na escrita parecem ser a última barreira 
de proteção contra o fracasso da linguagem. Muitas vezes, "a linguagem, no seu processo de discriminações e classificações, ao se defrontar com o impasse que coloca em xeque sua capacidade de atingir o grande Todo saber, deve lançar mão de algo que escapa ao saber", ressalta França Neto (2007, p. 82). Esse limite, que beira o insuportável, toca de um lado o belo e do outro o horror. Lacan $(1963 / 1998$, p. 776$)$ observa que a beleza é a "barreira extrema que nos proíbe o acesso a um horror fundamental". O belo é, assim, o guardião do desejo. A palavra, enquanto ponte para o belo, se mostra como recurso salutar perante o desamparo e consequente mal-estar. A impotência diante de tal situação reconduz a libido a encontrar novos investimentos via sublimação. Pulsões parciais que encontram um novo objeto e geram prazer em quem escreve e em quem lê.

Em "Personagens psicopáticos no palco", Freud (1905/1996f) analisa como se dá esse prazer obtido pelo leitor/espectador diante de uma criação literária. Os dramas desenvolvidos em certas peças de teatro e na literatura conseguem "abrir fontes de prazer ou gozo em nossa vida afetiva, assim como, no trabalho intelectual, o chiste ou o cômico abrem fontes similares" (p. 292). O enredo criado pelo escritor tem como pano de fundo a revolta contra a ordem divina que implantou o sofrimento. Freud conclui que o herói é um rebelde cuja grandeza é ressaltada ao se opor aos deuses. O prazer gerado no leitor decorre, portanto, de uma satisfação ante o infortúnio do herói, mas também ante o gozo de um personagem grandioso. Ao se rebelar contra a ordem incompreensível do universo, o herói assume as dores da humanidade.

Escritos com clara referência biográfica conseguem amenizar o malestar existencial. Kehl (2001) afirma que isso é possível graças à capacidade que narrativas dessa natureza têm de organizar o tempo, conferindo sentido às vidas narradas e mantendo a ilusão de que a existência é a construção de um destino. Impossibilitado de escapar das ameaças provenientes do corpo que envelhece, do estar no mundo e de seu mundo interno, o Eu busca, de acordo com Freud (1930/1996e), formas de obter satisfações substitutivas. São medidas paliativas que utilizamos para arrefecer sofrimentos e decepções. Ele destaca três medidas: "derivativos poderosos, que nos fazem extrair luz de nossa desgraça; satisfações substitutivas, que a diminuem; e substâncias tóxicas, que nos tornam insensíveis a ela" (p. 83). Entre as satisfações substitutivas, Freud ressalta as oferecidas pela arte que, graças ao papel da fantasia, se revela eficaz na diminuição do mal-estar existencial.

O Eu emprega formas diferentes para trazer alívio interno diante do sofrimento desencadeado pelo corpo, pelo mundo externo e pelos relacionamentos. Freud (1930/1996e) apresenta como exemplo de derivativo que nos possibilita extrair luz de nossa condição trágica a obra-prima de Voltaire e o conselho derradeiro de Cândido, e a 
atividade científica. Inerente a esses derivativos temos a arte (especificamente a escrita literária), a qual consegue extrair prazer da tragicidade da condição humana. A escrita criativa e poética parece propiciar um prazer daquele obtido pela contemplação da arte em geral. Cultivar o próprio jardim, conselho de Voltaire, nos aponta à dimensão estética da vida, mas vai além; aponta para o trabalho do cultivo, o trabalho psíquico de revolver a terra, plantar, adubar, regar.

Utilizar-se dos sofrimentos da vida como alavanca para se reinventar implica uma possível via de superação do sofrimento. Entrar em contato com a própria dor e transubstanciá-la em palavras escritas traz alívio e prazer. A literatura está repleta de exemplos. Carlos Heitor Cony, após vários anos sem escrever romance, produz "Quasememória" (1995), depois do divórcio, da morte de seu pai e do sofrimento de sua cadela Mila. Ele afirma numa entrevista concedida e publicada por Sandroni (2003, p. 123): "Comecei a escrever quando ela [Mila, a cadela] ficou doente. Foi um livro compartilhado a dois. Não entrou nenhum ser humano. Entrou muito da memória, provocada por um sentimento que tive". Em outra publicação, Cony faz um relato sobre período anterior à "Quase memória" em que ficou 20 anos sem escrever:

"parei porque tinha casado com uma mulher mais jovem, inteligente, advogada, que não gostava muito da vida intelectual. Eu vivia bem, estava felicíssimo - aí descobri que só escrevia quando estava infeliz. Quando voltei a ficar infeliz, com a doença da Mila, fui escrever de novo" (Cony, 2001, p. 35).

E continua: "tudo foi acabando, meu cabelo começou a cair, a mulher morreu. Quando fui ver, estava de novo encurralado, infeliz. Fui, então, escrever fogão outra vez - e estou escrevendo fogão até hoje" (p. 55). A escrita da palavra fogão remetia à dificuldade enfrentada na infância no tocante à pronúncia de algumas palavras. Cony trocava a letra " $g$ " pela " $d$ " na fala, mas não na escrita. Ao descobrir isso, passou a escrever a palavra "fogão" diversas vezes como forma de superar sua deficiência. A palavra escrita se tornou uma espécie de refúgio. Ele desabafa: "Eu só fui procurar a literatura por deficiências e carências. A literatura teve sempre para mim esse lado de abrigo, de apoio" (p. 37).

Outro ícone da poesia que superou o sofrimento através da palavra foi Cora Coralina, poetisa goiana. Após uma vida de privações, renúncias e humilhações, Coralina encontrou na velhice ocasião para poetizar sua história e suas memórias. Ela confessa em "Minha infância" (Coralina, 1965/1983, p. 175): 
Intimidada, diminuída. Incompreendida.

Atitudes impostas, falsas, contrafeitas.

Repreensões ferinas, humilhantes,

E o medo de falar...

E a certeza de estar sempre errando...

Aprender a ficar calada,

Menina abobada, ouvindo sem responder.

Daí, no fim da minha vida,

esta cinza que me cobre...

Este desejo obscuro, amargo, anárquico

de me esconder,

mudar o ser, não ser,

sumir, desaparecer,

e reaparecer

numa anônima criatura

sem compromisso de classe, de família.

Ela, de fato, acabou renascendo; deixou de ser Anna Lins e passou a ser Cora Coralina. A escrita poética lhe abriu caminhos para a reinvenção (poiesis) de si mesma.

A ação de escrever sobre questões singulares da vida, mas próprias do ser humano, de forma poética parece ser o que está presente no texto de escritores criativos. Freud (1908/1996c) enfatiza que a ars poetica está na capacidade do escritor disfarçar e suavizar seus devaneios, processo que pode ser estendido ao leitor, o qual é subornado pelo prazer estético oferecido pelo escritor.

A escrita literária pode ser, assim, pensada pelo viés da sublimação. Pulsões parciais são inibidas, deslocadas e desviadas de seu objetivo sexual inicial. Freud (1908/1996d) aponta a plasticidade presente nas pulsões e na sua capacidade em deslocar seus objetivos iniciais "sem restringir consideravelmente a sua intensidade. A essa capacidade de trocar seu objetivo sexual original por outro, não mais sexual, mas psiquicamente relacionado com o primeiro, chama-se capacidade de sublimação" (p. 174). Isso não significa que a escrita seja necessariamente destituída de gozo e de busca por prazer. Tanto a escrita quanto a leitura podem gerar prazer que remetem ao sexual.

Freud, no decorrer da estruturação de sua teoria, oscila entre duas concepções de sublimação, ora compreendendo-a como dessexualização, ora relacionando-a ao erotismo e criação de novos objetos de satisfação pulsional. A primeira concepção de sublimação, segundo Kupermann (2003), nos remete ao processo de substituição do alvo primordial da pulsão por outro 'dessexualizado'. Esse novo objetivo pulsional, adequado às exigências da civilização, pode ser representado pela arte e pela ciência. Desse modo, Freud (1908/1996d) coloca em lados opostos as exigências civilizatórias e a natureza pulsional do homem. A sublimação seria, portanto, uma 
defesa ante a exigência de renúncia pulsional e estaria submetida ao princípio de realidade. Entretanto, após as formulações sobre a pulsão de morte e a segunda tópica, Freud passou a conceber o processo sublimatório como independente do recalque.

A partir desses aportes metapsicológicos, Kupermann (2003) afirma que Freud destaca a sublimação como uma saída criativa do aparelho psíquico através da qual há uma mudança no objeto da satisfação pulsional, e não uma dessexualização do objetivo. Consequentemente, o psiquismo se empenha em criar objetos para a satisfação erótica do sujeito que sejam compartilháveis socialmente. Nesse sentido, a sublimação aponta "para o que, da ordem cultural, não se opõe ao erotismo e à vida pulsional" e para o fato de que "a criação sublimatória não estaria mais sendo regida por um princípio de realidade em oposição ao princípio de prazer, mas pelo próprio processo de simbolização que, por sua vez, é movida também pelo erotismo e pelo desejo" (p. 68).

Essa concepção já se mostrava embrionária em "Leonardo da Vinci e uma lembrança da sua infância" (Freud, 1910/1996h). Ao observar oscilações entre arte e ciência na história de Da Vinci, Freud deu início a uma reformulação de sua concepção de sublimação. Esse processo apontaria não mais a uma dessexualização pulsional, mas a "um processo erótico que tem raízes nas experiências sexuais infantis, e que está referido sobretudo às vicissitudes encontradas pelas pulsões de ver e de saber no processo de desenvolvimento psíquico do sujeito", afirma Kupermann (2003, p. 80). A busca obsessiva de Leonardo da Vinci pelo conhecimento em substituição à vida sexual é compreendida como um destino da pulsão - o recalque; e seu gênio artístico como tendo a sublimação por destino. A discussão sobre a criação poético-literária leva Freud ao campo da estética, no qual encontra instrumentos para a formulação de outra compreensão de sublimação. É nessa outra concepção que a sexualidade e o erotismo não precisam ser excluídos para que a produção cultural ocorra.

Green (1971/2002) afirma que há um prazer escoptofílico na leitura e escrita literária: "Uma obra literária é apreciada conforme o efeito emocional que provoca no leitor, mais do que a inteligência que dela emana, mesmo se for preciso muita inteligência por parte do escritor para produzir esse efeito" (p. 235). Rubem Alves (2005, p. 98) descreve esse prazer obtido através das pulsões parciais sublimadas como fazer amor com as palavras: "Na literatura são as palavras que fazem amor com a gente. A palavra nos toca, o corpo e a alma reverberam e atestam a verdade da palavra. Literatura é um jeito de fazer amor à distância".

A escrita mediadora do prazer de ver/ler está visceralmente conectada ao corpo que pulsa. "Não se pode escrever sem a força do corpo", afirma Duras (1994, p. 23), "o escrito é o grito das feras 
noturnas". Corpo, pulsão e escrita se sustentam e encontram caminhos para a obtenção de alívio e prazer. O movimento do inconsciente na produção literária se assemelha ao que acontece na produção dos sonhos. São meios de ludibriar o supereu e o princípio de realidade, de forma a obter prazer ante a impossibilidade real de gozo. A poiesis do eu presente na escrita autobiográfica envolve uma postura perante a própria experiência e suas dimensões intrínsecas como as problemáticas do ser, do conhecimento, da verdade, da forma de conduzir a própria vida e as relações com os outros (Lima, Viana, \& Lazzarini, 2011).

Há, portanto, na produção literária um trabalho de se debruçar sobre as palavras, mas também um trabalho psíquico que, aproveitando-se do primeiro, dá vazão às pulsões parciais que se satisfazem de forma sublimada. As moções pulsionais e o trabalho psíquico requerido pela pulsão se manifestam na necessidade quase visceral de escrever algo. Assim como o sintoma, a produção literária implica realização de desejos e caminhos para descarga pulsional. A criação literária se mostra, muitas vezes, como "uma via de transformação e prazer onde antes havia sofrimento", afirma Carvalho (2006, p. 15), pois transforma o sofrimento psíquico em uma experiência subjetiva compartilhável. Portanto, há o laço social de um outro a quem o sujeito escritor destina sua produção, mesmo que seja alguém a quem nunca conheceu.

Contudo, há a necessidade de contato com a dor para que ela encontre consolo nas palavras. Muitas vezes, o silêncio, o isolamento e a solidão, como meios de acesso à dor, se fazem necessários. $O$ trabalho de imersão em um mundo interno é belamente descrito por Carlos Drummond de Andrade em "Procura da poesia" (1962/2008, pp. 248-249). Antes de poetizar acerca da natureza, das coisas da vida ou da própria vida, o escritor necessita mergulhar em si mesmo, tendo o silêncio como guia para que possa, através das palavras, se escrever e se inscrever no poema:

Penetra surdamente no reino das palavras.

Lá estão os poemas que esperam ser escritos.

Estão paralisados, mas não há desespero,

há calma e frescura na superfície intata.

Ei-los sós e mudos, em estado de dicionário.

Convive com teus poemas, antes de escrevê-los.

(...)

Chega mais perto e contempla as palavras.

Cada uma

tem mil faces secretas sob a face neutra

e te pergunta, sem interesse pela resposta, pobre ou terrível, que lhe deres:

Trouxeste a chave? (Andrade, 1962/2008) 
A poesia é compreendida como algo que se apodera do escritor se ele tiver a chave. Qualquer objeto, imagem, lembrança pode se tornar peça para a produção poética. "A poesia não é alheia - a poesia, como veremos, está logo ali, à espreita. Pode saltar sobre nós a qualquer instante", declara Borges (2000, p. 11). Porém, ressaltamos que para a psicanálise o objeto de inspiração para a escrita não é de todo aleatório. Assim como nos sonhos, o inconsciente se utiliza de situações e objetos aparentemente desconexos que remetem a desejos reprimidos e que geram prazer (Freud, 1900/1996a). Assim, a escrita literária é um caminho encontrado pelo inconsciente para escrever e inscrever o desejo e o sujeito do desejo. É preciso, contudo, conviver com os próprios poemas antes de escrevê-los, aconselha Drummond. Talvez a chave seja conviver com os fantasmas e tristezas até que se alcance o sublime pela palavra.

Possuir a chave pode também se referir ao mistério dos recintos fechados. Rubem Alves usa o quarto do sótão do casarão de seu avô, nomeado de o 'quarto do mistério', como metáfora do que há de mais íntimo no psiquismo. Em sua infância, tinha prazer enorme em roubar a chave do quarto. Ele confessa: "Minha alma é um quarto onde os objetos mais estranhos estão colocados, um ao lado do outro, sem ordem, sem nenhuma intenção de fazer sentido" (Alves, 1995, p. 11). Iberê Camargo, artista plástico brasileiro, faz analogia semelhante: "A memória é a gaveta dos guardados, repito para sublinhar. (...). No andar do tempo, vão ficando as lembranças; os guardados vão se acomodando em nossas gavetas interiores" (2009, p. 31). Entrar no quarto do mistério ou abrir a gaveta dos guardados não significa que o mistério será esgotado. O pulsar inconsciente não cessa, e suas moções estão sempre em movimento e em busca de descarga.

Se o texto escrito remonta ao quarto do mistério do poeta e se há a demanda por um trabalho psíquico de construção da escrita, a sublimação parece apontar para algo diferente do mero disfarce das fantasias. Da mesma forma que no sintoma, a escrita possui um sentido inconsciente, como demonstrado por Freud (1917/1996g). A escrita, comparada ao sintoma, aponta para a substituição de algo que não aconteceu. Pulsões não satisfeitas ou desviadas de seu objeto encontram vias alternativas. É O inconsciente que escreve o desejo do sujeito. Fernando Pessoa (1934/2003, p. 394) declara: "Depois de escrever, leio.../Porque escrevi isto? Onde fui buscar isto?/De onde veio isto? Isto é melhor do que eu.../Seremos nós, neste mundo, apenas canetas com tinta/Com que alguém escreve a valer o que nós aqui traçamos?...".

Green (1971/2002), ao comparar as produções do delírio, do texto e da interpretação, afirma que assim como no delírio, o texto também é construído em torno de um núcleo de verdades: a verdade do 
desejo de escrever e de ser lido; a verdade do fantasma, tentativa de busca do objeto perdido; a verdade da ilusão, o afastamento do real que permite o escritor falar de seus desejos; a verdade histórica, 0 texto como produto da história daquele que o escreveu e que fala à história do que o lê. Esse núcleo de verdades auxilia na construção do texto a partir dos processos de ligação e incide sobre a secundaridade do texto. Há uma exigência de trabalho que se manifesta no "jogo de claro-escuro pelo qual a relação do velar-desvelar do inconsciente deixa sempre na sombra a eficácia dinâmica do texto, para só se prender à sua eficácia literária" (p. 232). Essa dinâmica remete à ação psíquica que constrói a realidade interna e, consequentemente, a subjetividade. Assim como o sintoma e o delírio falam do sujeito que os produzem, o texto vela e revela esteticamente o sujeito que 0 escreve.

Concordamos com Freud (1911/2004, p. 69):

A arte promove uma reconciliação entre os dois princípios por uma via peculiar. Originalmente o artista é uma pessoa que, por não conseguir se haver com a exigência de renúncia à satisfação pulsional de início requerida pela realidade, afastouse da realidade e, no mundo da fantasia, deu livre curso a seus desejos eróticos e ambiciosos. No entanto, é capaz de encontrar o caminho de volta desse mundo da fantasia à realidade, graças a um talento especial para moldar suas fantasias em realidades de um novo tipo, aceitas pelas pessoas como imagens valiosas da realidade.

A partir da capacidade de ir e vir do mundo da fantasia, o escritor consegue, via cultura, certa descarga pulsional sem a atuação direta no real. Além disso, obtém uma espécie de prazer secundário com o reconhecimento e aceitação social com suas imagens da realidade, que são desejos condensados nos textos produzidos, sejam eles escritos, falados, pintados ou esculpidos.

\section{Narrativas e rememorações: a poiesis do eu na velhice}

A autobiografia é, segundo Bakhtin (1979/2010), uma forma transgrediente imediata em que 0 sujeito pode se objetivar artisticamente. Nesse sentido, a transgrediência consiste na disposição do autor em se colocar fora do que está sendo escrito. Nas autobiografias, é a capacidade de se tornar um outro contemplador de si mesmo. Bakhtin afirma que esse componente fornece elementos estéticos para o personagem criado. Entre os valores artísticos, apesar de ser o menos transgrediente à autoconsciência, o valor biográfico "pode organizar não só a narração sobre a vida do outro, 
mas também o vivenciamento da própria vida e a narração sobre a minha própria vida, pode ser forma de conscientização, visão e enunciação da minha própria vida" (p. 139). É esse valor que provê as formas e os valores da 'estética da vida' e a (re)construção do próprio sujeito através da escrita.

Narrar a própria história transforma o autor em um outro para si mesmo. $\mathrm{O}$ autor se põe diante de um espelho, cuja imagem reflete 0 eu passado e o eu presente. A ação de recordar-se, afirma Bakhtin (1979/2010), se aproxima narração literária, pois "qualquer memória do passado é um pouco estetizada" (p. 140). É uma busca por reconstrução (e não um relato factual) do próprio passado, tendo em vista as instanciações que a história e o presente impõem ao sujeito. O que fica na memória e na consciência do sujeito são apenas recordações, uma visão esfumaçada e fragmentada da constituição da própria história. As construções que a escrita autobiográfica produz apontam para lapsos de compreensão, como em um quebracabeça; cada busca gera o encontro de novas peças. Freud (1937/1996b), ressalta que "o analista completa um fragmento da construção e o comunica ao sujeito da análise, de maneira a que possa agir sobre ele; constrói então outro fragmento a partir do novo material (...) lida com este da mesma maneira e prossegue" (p. 279). As narrativas implicam, como afirma Benjamin (1936/2012), troca de experiências e histórias de vida, e relações inter-humanas. Apesar de a escrita ser solitária, está permeada pelo outro, o possível leitor. Essa possiblidade de transmitir algo de si a outros é uma busca presente na vida dos idosos. Rubem Alves (2003) escreveu "Quando eu era menino" às suas netas, com a intenção de lhes contar como era a vida na primeira metade do século XX. De certa forma, Alves resgata o ato de narrar que parece ser próprio da avosidade ${ }^{\times 2}$ e cuja finalidade é transmitir aspectos da ancestralidade, valores e tradições familiares. Mesmo quando a narrativa não é endereçada a um outro específico, um outro imaginário está presente.

Reviver o passado disfarçado nas lembranças se torna inevitável na velhice. Iberê Camargo relata: "As coisas estão enterradas no fundo do rio da vida. Na maturidade, no ocaso, elas se desprendem e sobem à tona, como bolhas de ar" (2009, p. 30). A forma de narrar os fatos passados, as escolhas feitas do que contar, as lembranças que despertaram outras lembranças vão construindo um vitral existencial em que a subjetividade vai se desvelando. Portanto, são representações e interpretações da realidade que revelam e valorizam a subjetividade do indivíduo. A autobiografia, segundo Molloy (2003), é

uma representação, ou seja, um tornar a contar pois a vida a que supostamente se refere, por si mesma, é uma construção narrativa. A vida é sempre, necessariamente, uma história; 
história que contamos a nós mesmos como sujeitos, através da rememoração. A autobiografia não depende de acontecimentos, mas da articulação destes eventos armazenados na memória e reproduzidos através da rememoração e verbalização (p. 19).

A dificuldade de se distinguir veracidade de ficção nas narrativas aproxima, muitas vezes, a autobiografia do romance. A estetização das lembranças, algo inevitável segundo Bakhtin (1979/2010), impede a separação clara entre o que de fato aconteceu e o que foi fantasiado pelo escritor. Saramago (1997, p. 9) afirma que tudo é autobiografia, que a vida de cada um de nós a estamos contando em tudo quanto fazemos e dizemos, nos gestos, na maneira como nos sentamos, como andamos e olhamos, como viramos a cabeça ou apanhamos um objeto do chão. Pergunto-me se o que move o leitor à leitura não será a secreta esperança ou a simples possibilidade de vir a descobrir, dentro do livro, mais do que a história contada, a pessoa invisível, mas onipresente, que é o autor.

Apesar da impossibilidade de se escrever a vida e todas as lembranças de forma coesa e completa, a autobiografia fornece pistas sobre a subjetividade do escritor. Nosso olhar se volta particularmente para a experiência compartilhada através do texto. A poiesis de si indica uma forma de amenizar o mal-estar desencadeado pelo desamparo. Reescrever o passado pode criar condições para a reescrita da própria subjetividade e para a busca de uma forma de unidade da própria identidade. Ante a fragmentação gerada pela modernidade, $\mathrm{o}$ ato autobiográfico remonta o passado e aponta para o futuro. A historicidade parece ser reestabelecida.

A angústia diante da proximidade da morte e o desejo de imortalidade parecem gerar uma necessidade de ordenação da própria vida. O desejo de permanecer vivo na memória, deixando um legado simbólico através da qual será lembrado após a morte, está na base da necessidade que o velho tem de narrar sua história (Lima, Coelho, \& Günther, 2011). Talvez o fator originário do ritual de se escrever um testamento seja o desejo de imortalidade. Rubem Alves (2004) escreve que o testamento é o que resta, "depois de feitas todas as somas e subtrações. É aquilo que se passa às mãos dos que continuarão a viver". E continua: "No fundo o que se deseja é a imortalidade: continuar vivos naqueles que comem o que thes oferecemos como herança. Vejam só que coisa mais pobre: uma herança onde as coisas deixadas são palavras" (p. 65).

Podemos pensar, portanto, a poiesis do eu na velhice como uma possível via de escape à angústia da castração real - a morte. Uma vez que o tempo passa a ser experimentado sem as obrigações próprias da vida adulta e da maturidade, o velho tem a oportunidade de fazer rearranjos libidinais. O desprendimento de certos deveres na velhice pode possibilitar o afrouxamento da censura superegoica e 
permitir ao velho construir uma forma diferente de experimentar a si mesmo e ao outro. Em sua última crônica para o jornal "A Folha de $S$. Paulo", Rubem Alves (2011) desabafa:

"Há um cansaço. A velhice é o tempo do cansaço de todas as coisas (...) meus 78 anos estão pesando. A obrigação: é isso o que pesa. E é por isso [que] vou parar de escrever: porque estou velho, estou cansado, quero me livrar dos malditos deveres que me dão ordens desde que me conheço por gente".

Rubem Alves parou de escrever o que the era obrigatório, mas permanece escrevendo seu desejo por mero prazer ou apenas para suprir sua demanda interna. Em pesquisas acerca dos processos psíquicos que envolvem uma boa velhice, Tornstam (1999) observou que alguns idosos realizam mudanças na perspectiva da vida, do tempo e das relações sociais. Esses idosos conseguiram remanejar seus investimentos libidinais e construíram vias salutares para não sucumbirem à neurose ou ao sofrimento psíquico. Seus estudos demonstraram que o 'velho sábio' seria aquele que redescobriu aspectos encobertos do próprio ego com consequente diminuição do egocentrismo e da obsessão pelo corpo perfeito e eternamente jovem. Há, nesses casos, um desprendimento no tocante às exigências exteriores de experimentação do tempo. Como substituição às constantes exigências sociais parece brotar um desejo de aproveitar melhor o tempo com atividades prazerosas.

Em entrevista, Cony (Schwartz, 2009) afirmou: "Eu já estou numa idade avançada. Mais de 80 anos e cinco empregos. São cinco chefes. (...) Realmente, é uma tourada. Mas eu não saberia fazer outra coisa". Em outra entrevista, Cony (Bernardo, 2012) declarou: "não tenho mais nada a escrever. Mas vou continuar escrevendo assim mesmo". Alves (2005, p. 28), igualmente afirma:

"E vou escrever. Escrever é minha maneira de ser. (...) Vou escrever as 'memórias da minha vida': por prazer e para os meus filhos e amigos. Eles têm curiosidade sobre 0 meu passado e eu também, é claro, se minha bonificação não se esgotar".

Desprender-se, mas manter o gozo com o que se fazia antes ou com novas atividades, aponta para o desprendimento da própria vida rumo à finitude. Nessa perspectiva, podemos pensar na rememoração como uma forma de, ao falar sobre o passado, o velho ir se desprendendo do excesso, das lembranças dolorosas, e de buscar novas catexias. Alves e Cony continuam a utilizar a escrita como formas de obter e gerar prazer. 


\section{Por uma estética e uma poética da velhice}

Em pesquisa sobre a velhice, Bosi (1979/2007) afirma que muitas vezes resta ao velho retrair-se de seu lugar social e acomodar-se em suas memórias, pois, na modernidade, ele foi retirado de seu lugar social de reconhecimento simbólico. Acontece que as lembranças carecem de um Outro para ter ressonância e dar contornos à identidade. As memórias, quando destituídas de escuta, podem se transformar em reminiscências neuróticas, soltas e repetitivas. Bosi observa que "o grupo é suporte da memória se nos identificamos com ele e fazemos nosso seu passado" (1979/2007, p. 414). Na ausência do suporte dos outros, o sujeito pode encontrar esse suporte nos leitores para quem escreve. Larrosa (2006) e Macedo (2006) evidenciam a poiesis do eu nos diários, cartas e memoriais acadêmicos. A poiesis do eu nos vários gêneros de escrita e formas de expressão e narração da própria história é possível porque o processo de produção da escrita garante a presença do Outro.

A linguagem poietica é lugar no qual o sujeito se reconstrói e se reconhece. Os traços mnêmicos que tomam forma e contorno à medida que são narrados e recontados apontam para uma escritura psíquica que não se apaga, nem se esgota. Além disso, o vínculo que se estabelece entre narrador e ouvinte/leitor pode gerar um compromisso para o autor continuar escrevendo sua vida.

Ressaltamos a necessidade de o idoso continuar escrevendo e (re)contando as impressões e interpretações que têm de si, mesmo num contexto em que se espera dele apenas decrepitude, silêncio e morte. Encontram-se entreabertas ao sujeito velho as possibilidades de aprender a lidar com os ideais culturais atuais, e de reconstruir seus ideais e sua própria identidade. A (re)criação de si através de narrativas pode ser a via de construção de um novo ideal de velhice, mais belo e prazeroso. Isso implica aceitar limitações e impossibilidades, elaborar lutos, revisitar o passado e reconstruir-se no presente com projeções futuras.

Freud (1930/1996e) afirma que o programa de tornar-se feliz imposto pelo princípio do prazer, apesar de impossível, conduz o sujeito a buscar sempre vias de satisfação. Não existe regra única que se aplique a todos, pois cada sujeito constrói o seu próprio caminho. Além disso, vários fatores contribuem para as escolhas: (a) quanta satisfação real o sujeito consegue obter do mundo externo; (b) até onde é capaz de ir para tornar-se independente do mundo externo; (c) quanta força tem ao seu dispor para modificar o mundo e adaptá-lo a seus desejos. Nesse sentido, a história de vida do sujeito e a busca por satisfação libidinal desenvolvidas ao longo da vida são cruciais para que, na velhice, o sujeito continue a obter satisfação. 
Ainda sobre os possíveis caminhos na busca pela felicidade, Freud afirma que muitas pessoas são incapazes de conduzir imperativamente a direção de seus interesses. A análise de Beauvoir parece reforça essa tese: "se o aposentado fica desesperado com a falta de sentido de sua vida presente, é porque o sentido de sua existência sempre Ihe foi roubado" (1970/1990, p. 668). Diante dessa incapacidade, um caminho sugerido por Freud (1930/1996e), seria o da ressignificação do sentido do trabalho. A aposentadoria e, muitas vezes, a própria condição de velho privam o sujeito de atividades que Ihe proporcionavam prazer e vínculos sociais. Notamos com frequência a tentativa de familiares e cuidadores de preencher 0 tempo do idoso com atividades sem sentido. A mera ocupação do tempo não proporciona prazer; não constitui uma forma significativa de agir no mundo. Arendt ressalta que "a ação, com todas as suas incertezas, é como um lembrete sempre presente de que os homens, embora tenham de morrer, não nasceram para morrer, mas para iniciar algo novo" (1967/2005, p. 194). O objeto de investimento escolhido deve trazer para o velho possibilidades para uma (re)construção de si mesmo via ação significativa.

A estetização e construção de um sentido para a vida são possíveis na medida em que o sujeito faz remanejamentos libidinais frente às castrações. O corpo sem jovialidade e a aproximação da morte são vividos como castrações, simbólicas e reais, que compelem o velho a uma busca por representações e pontos de apoio para reinvestimentos. Rubem Alves indaga:

"Também os velhos querem amar e ser amados. Mas quem nos amará? Quero ser amado como escritor, como avô carinhoso, como jardineiro - mas não só. Para onde é que vai a beleza dos velhos? Quem, sem consolo ou mentira, Ihes dirá que eles são belos?" (2005, p. 103).

Estudos no campo da Psicologia Clínica, da Psicologia Social e da Psicanálise têm demonstrado as reverberações da rememoração na subjetividade de idosos. As pesquisas de Cabral, Amaral e Brandão (2009) e Leão e Glígio (2005) destacam as oficinas de revisão de vida como instrumento salutar no auxílio ao idoso. A partir do compartilhamento de suas histórias de vida com outros velhos, o sujeito encontra, não apenas acolhimento e compreensão, mas possibilidade de estabelecer vínculos afetivos com outros sujeitos coetâneos. A identificação entre os participantes do grupo auxilia o velho a elaborar lutos de pessoas que testemunharam sua história de vida. Brandão (2003, p. 161), em outra pesquisa, observa que ao compartilhar lembranças

"tempos individuais se cruzam, formando um tempo coletivo. 
Este compartilhar dá lugar a uma nova solidariedade (...). Assim, a indiferença, marca das grandes cidades, desaparece dando lugar a uma nova trama de relações. Assim os grupos, formados aleatoriamente, tecem uma nova trama de (re)significados".

Essas oficinas oferecem espaço para vinculação e estimulam os velhos a escrever textos autobiográficos. Muitas vezes recortes antigos de jornais e revistas, músicas e poemas são utilizados na escrita poietica das memórias. A ressignificação e reconstrução da identidade, possibilitadas pela rememoração e compartilhamento das memórias, ajudam o velho a se redefinir ante as mudanças da velhice e a refazer seu lugar social e suas relações. Ao se apropriar de sua história, o velho se (re)apropria de sua identidade, de sua escrita, de seu corpo e de seu tempo. Estudos e pesquisas realizadas por Goldfarb $(1998 ; 2004)$ e Mucida $(2004 ; 2009)$, demonstram, através da psicanálise, que a abertura do sujeito para novos investimentos libidinais faz emergir novos sentidos para a própria velhice.

O futuro está entreaberto para o sujeito. O acolhimento para as histórias dos velhos passa pela reconstrução de seu lugar social, garantindo-Ihe o direito de fala, seja no contexto familiar, no convívio social ou nos grupos de psicoterapia ou de apoio. Por mais que o tempo vivido por esse sujeito seja outro, com tecnologias, relações sociais e familiares diferentes das atuais, é preciso reconhecer seu lugar na história familiar e social. "Pode acontecer então que voltar atrás seja uma maneira de seguir adiante", nos ensina Berman (1982/2007, p. 49). A angústia pelo tempo que foge talvez possa ser amenizada pelas lembranças e afetos que permanecem, e pelos ouvidos acolhedores do Outro.

\section{Referências}

Alves, R. (1995). O quarto do mistério. Campinas, SP: Papirus.

Alves, R. (2001). As cores do crepúsculo. Campinas, SP: Papirus.

Alves, R. (2003). Quando eu era menino. Campinas, SP: Papirus.

Alves, R. (2004). Se eu pudesse viver minha vida novamente. Campinas, SP: Verus.

Alves, R. (2005). A maçã e outros sabores. Campinas, SP: Papirus.

Alves, R. (2011). Despedida. Folha de São Paulo, Cotidiano (01 nov). Recuperado em 06 de dezembro, 2012, de: http://www1.folha.uol.com.br/fsp/cotidian/ff0111201105.htm

Andrade, C. (2008). Antologia poética. Rio de Janeiro: Record. (Obra original publicada em 1962).

Arendt, H. (2005). Trabalho, obra, ação. (A. Correia, Trad.). Cadernos de Ética e Filosofia Política 7(2), 175-201. (Obra 
original publicada em 1967).

Aristóteles. (1991). Ética a Nicômaco (4ed.). (L. Vallandro \& G. Bornheim, Trads.). São Paulo: Nova Cultural.

Aristóteles. (2007). Poética. (A. Valente, Trad.). Lisboa: Fundação Calouste Gulbenkian.

Bakhtin, M. (2010). Estética da criação verbal (5ed.). (P. Bezerra, Trad.). São Paulo: Martins Fontes. (Obra original publicada em 1979).

Baumgarten, A. (1954). Reflexions on poetry. (K. Aschenbrenner \& W. Holther, Trads.). Los Angeles, EUA: University of California Press. (Obra original publicada em 1735).

Beauvoir, S. (1990). A velhice. (M. Martins, Trad.). Rio de Janeiro: Nova Fronteira. (Obra original publicada em 1970).

Benjamin, W. (2012). O narrador. In W. Benjamin (Org.). Obras escolhidas. Vol. 1. (8ed. ver., pp. 213-240). (S. Rouanet, Trad.). São Paulo: Brasiliense. (Obra original publicada em 1936).

Berman, M. (2007). Tudo que é sólido desmancha no ar. (C. Moisés \& A. Ioriatti, Trad.). São Paulo: Cia das Letras. (Obra original publicada em 1982).

Bernardo, A. (2012). Carlos Heitor Cony: herói da resistência. [Entrevista realizada em setembro de 2012]. Recuperado em 06 de dezembro, 2012, de: http://www.saraivaconteudo.com.br/Entrevistas/Post/47884

Borges, J. (2000). Esse ofício do verso. (J. M. Macedo, Trad.). São Paulo: Cia das Letras.

Bosi, E. (2007). Memória e sociedade: lembranças de velhos (14ed.). São Paulo: Cia das Letras. (Obra original publicada em 1979).

Brandão, V. (2003). Memória autobiográfica. In B. Côrte, E. Mercadante, \& I. Arcuri (Orgs.). Velhice, envelhecimento, complex(idade) (pp.155-182). São Paulo: Vetor.

Cabral, P, Amaral, R., \& Brandão, V. (2009). Oficinas de memória autobiográfica. Kairós, 12(1), 257-274.

Camargo, I. (2009). Gaveta dos guardados. (A. Massi. Org.). São Paulo: Cosac Naify.

Carvalho, A. (2006). Limites da sublimação na criação literária. Estudos de Psicanálise, 29, 15-24.

Cony, C. (1995). Quase-memória. São Paulo: Cia das Letras.

Cony, C. (2001). Cadernos de Literatura Brasileira - Carlos Heitor Cony. Rio de Janeiro: Instituto Moreira Salles.

Coralina, C. (1983). Poemas dos becos de Goiás e estórias mais. Mariana, SP: Global. (Obra original publicada em 1965).

Duras, M. (1994). Escrever. (R. Figueiredo, Trad.). Rio de Janeiro: Rocco.

Eagleton, T. (2010). A ideologia da estética (edição digital). Rio de Janeiro: Zahar. (Obra original publicada em 1990). 
França Neto, O. (2007). Freud e a sublimação. Belo Horizonte: Editora UFMG.

Freud, S. (1996a). A interpretação dos sonhos. In S. Freud (Ed.). Edição Standard Brasileira das Obras Psicológicas Completas de Sigmund Freud. (J. Salomão, Trad.) (vol. 4). Rio de Janeiro: Imago. (Obra original publicada em 1900).

Freud, S. (1996b). Construções em análise. In S. Freud (Ed.). Edição Standard Brasileira das Obras Psicológicas Completas de Sigmund Freud. (J. Salomão, Trad.) (vol. 23, pp. 274-287). Rio de Janeiro: Imago. (Obra original publicada em 1937).

Freud, S. (1996c). Escritores criativos e devaneio. In S. Freud (Ed.). Edição Standard Brasileira das Obras Psicológicas Completas de Sigmund Freud. (J. Salomão, Trad.) (vol. 9, pp. 135-143). Rio de Janeiro: Imago. (Obra original publicada em 1908[1907]).

Freud, S. (1996d). Moral sexual 'civilizada' e doença nervosa moderna. In S. Freud(Ed.). Edição Standard Brasileira das Obras Psicológicas Completas de Sigmund Freud. (J. Salomão, Trad.) (vol. 9, pp. 169-186). Rio de Janeiro: Imago. (Obra original publicada em 1908).

Freud, S. (1996e). O mal-estar na civilização. In S. Freud (Ed.). Edição Standard Brasileira das Obras psicológicas completas de Sigmund Freud. (J. Salomão, Trad.) (vol. 21, pp. 65-148). Rio de Janeiro: Imago. (Obra original publicada em 1930[1929]).

Freud. S. (1996f). Personagens psicopáticos no palco. In S. Freud (Ed.). Edição Standard Brasileira das Obras Psicológicas Completas de Sigmund Freud. (J. Salomão, Trad.) (vol. 7, pp. 292-297). Rio de Janeiro: Imago. (Obra original publicada em 1905).

Freud, S. (1996g). Uma dificuldade no caminho da psicanálise. In S. Freud (Ed.). Edição Standard Brasileira das Obras Psicológicas Completas de Sigmund Freud. (J. Salomão, Trad.) (vol. 17, pp. 145-153). Rio de Janeiro: Imago. (Obra original publicada em 1917).

Freud, S. (1996h). Leonardo da Vinci e uma lembrança de sua infância. In S. Freud (Ed.). Edição Standard Brasileira das Obras Psicológicas Completas de Sigmund Freud. (J. Salomão, Trad.) (vol. 11, pp. 67-141). Rio de Janeiro: Imago. (Obra original publicada em 1910).

Freud, S. (2004). Formulações sobre os dois princípios do acontecer psíquico. In S. Freud (Ed.). Escritos sobre a psicologia do inconsciente. (Vol. 1, pp. 63-77) (L. A. Hanns, Trad.). Rio de Janeiro: Imago. (Obra original publicada em 1911).

Goldfarb, D. (1998). Corpo, tempo e envelhecimento. São Paulo: Casa do psicólogo.

Goldfarb, D. (2004). Do tempo da memória ao esquecimento da história: estudo psicanalítico das demências. Tese de 
doutorado. Universidade de São Paulo, São Paulo, SP, Brasil.

Green, A. (2002). Literatura e psicanálise: a desligação. (L. Vassallo, Trad.). In L. Lima (Org.). Teoria da literatura em suas fontes (pp. 221-251). Rio de Janeiro: Civilização Brasileira. (Obra original publicada em 1971).

Kehl, M. (2001). Nós, sujeitos literários. Textura, 1(1), 35-41.

Kupermann, D. (2003). Ousar rir: humor, criação e psicanálise. Rio de Janeiro: Civilização Brasileira.

Lacan, J. (1998). Kant com Sade. In J. Lacan (Ed.). Escritos. (pp. 776-803). (V. Ribeiro, Trad.). Rio de Janeiro: Zahar. (Obra original publicada em 1963).

Larrosa, J. (2006). Ensaio, diário e poema como variantes da autobiografia. In E. Souza, \& M. Abrahão (Orgs.). Tempos, narrativas e ficções: a invenção de si (pp.183-202). Porto Alegre: EDIPUCRS.

Leão, M., \& Glígio, J. (2005). A oficina de revisão de vida como um método de intervenção psicológica com idosos. Kairós, 8(2), 235-248.

Lima, P., Coelho, V., \& Günther, I. (2011). Envolvimento vital: um desafio da velhice. Geriatria \& Gerontologia, 5(4), 261-268.

Lima, P., Viana, T., \& Lazzarini, E. (2011). "Velhice? Acho ótima, considerando a alternativa". Reflexões sobre velhice e humor. Revista Mal-estar e Subjetividade, 11(4), 1.597-1.618.

Macedo, R. (2006). Currículo, prosa e poesia. In E. Souza, \& M. Abrahão (Orgs.). Tempos, narrativas e ficções: a invenção de si. (pp. 239-244). Porto Alegre: EDIPUCRS.

Molloy, S. (2003). Vale o escrito: a escritura autobiográfica na América Hispânica. (A. Santos, Trad.). Chapecó, RS: Editora Argos.

Mucida, A. (2004). O sujeito não envelhece. São Paulo: Autêntica.

Mucida, A. (2009). Escrita de uma memória que não se apaga. São Paulo: Autêntica.

Oliveira, A., Vianna, L., \& Cárdenas, C. (2010). Avosidade: visões de avós e de seus netos no período da infância. Revista Brasileira de Geriatria e Gerontologia, 13(3), 461-474.

Pessoa, F. (2003). Às vezes... In: F. Pessoa(Ed.). Obra poética. (p. 394). Rio de Janeiro: Nova Aguilar. (Poema original escrito em 1934).

Sandroni, C. (2003). Carlos Heitor Cony: quase Cony. Rio de Janeiro: Relume Dumará.

Saramago, J. (1997). Cadernos de Lanzarote. São Paulo: Cia das Letras.

Schwartz, C. (2009). Carlos Heitor Cony. [Entrevista realizada em setembro de 2009]. Recuperado em 30 de janeiro de 2013 de: http://www.rascunho.gazetadopovo.com.br/carlos-heitor-cony/

Tornstam, L. (1999). Transcendence in later life. Generations, 23(4), 
10-14.

\section{Endereço para correspondência \\ Priscilla Melo Ribeiro de Lima}

Universidade Federal de Goiás

Faculdade de Educação

Rua 235, Setor Universitário, CEP 74605-050, Goiânia, GO, Brasil

Endereço eletrônico: primlima@gmail.com

\section{Terezinha de Camargo Viana}

Universidade de Brasília

Instituto de Psicologia, Programa de Pós-graduação em Psicologia Clínica e Cultura Campus Universitário Darcy Ribeiro, ICC, Ala Sul, Bloco A, Térreo, CEP 70910-900, Brasília, DF, Brasil

Endereço eletrônico: tcviana@unb.br

\section{Sostenes Cezar de Lima}

Universidade Estadual de Goiás

Mestrado Interdisciplinar em Educação, Letras e Tecnologia

Avenida Juscelino Kubitschek, 146, Jundiaí, CEP 75110-390, Anápolis, GO, Brasil

Endereço eletrônico: limasostenes@gmail.com

Recebido em: $12 / 08 / 2014$

Aceito em: 01/12/2014

\section{Notas}

* Doutora em Psicologia Clínica e Cultura pela Universidade de Brasília.

** Pós-doutorado em Psicologia, Instituto Superior de Psicologia Aplicada, Lisboa, Portugal.

*** Doutorado em Linguística pela Universidade de Brasília. Pós-doutorando em Ciências da Religião pela Pontifícia Universidade Católica de Goiás.

${ }^{1}$ Utilizamos a edição eletrônica em formato epub que impossibilita a numeração de páginas.

${ }^{2}$ Laço de parentesco entre avós e netos que envolve a assunção, por parte dos avós, de uma função derivada das funções parentais de cuidado (Lima, Coelho, \& Günther 2011; Oliveira, Vianna, \& Cárdenas, 2010). 